[CL]

\title{
A detailed chronology of the Australasian impact event, the Brunhes-Matuyama geomagnetic polarity reversal, and global climate change
}

\author{
David A. Schneider ${ }^{a}$, Dennis V. Kent ${ }^{b}$ and Gilberto A. Mello ${ }^{b}$ \\ a Woods Hole Oceanographic Institution, Woods Hole, MA 02543, USA \\ ${ }^{b}$ Lamont - Doherty Geological Observatory of Columbia University, Palisades, NY 10964, USA
}

Received November 14, 1991; revision accepted May 1, 1992

\begin{abstract}
A mechanism had been recently proposed to show how an impact event can trigger a geomagnetic polarity reversal by means of rapid climate cooling. We test the proposed mechanism by examining the record from two high sedimentation rate (8-11 cm/kyr) deep-sea sediment cores (ODP Sites 767 and 769) from marginal seas of the Indonesian archipelago, which record the Australasian impact with well-defined microtektite layers, the Brunhes-Matuyama polarity reversal with strong and stable remanent magnetizations, and global climate with oxygen isotope variations in planktonic foraminifera. Both ODP cores show the impact to have preceded the reversal of magnetic field directions by about 12 kyr. Both records indicate that the field intensity was increasing near the time of impact and that it continued to increase for about 4 kyr afterwards. Furthermore, the oxygen isotope record available from sediments at ODP Site 769 shows no indication of discernible climate cooling following the impact: the microtektite event occurred in the later part of glacial Stage 20 and was followed by a smooth warming trend to interglacial Stage 19. Thus the detailed chronology does not support the previously proposed model which would predict that a decrease in geomagnetic field intensity resulted from a minor glaciation following the impact event. We conclude that the evidence for a causal link between impacts and geomagnetic reversals remains insufficient to demonstrate a physical connection.
\end{abstract}

\section{Proposed impact-geomagnetic reversal link}

Recently Muller and Morris suggested that Earth's magnetic field may respond to sudden climate changes induced by cataclysmic impact events $[1,2]$. This theory proposes that the dust lofted into the atmosphere by a large bolide impact may result in sudden global cooling causing a substantial amount of ocean water to be rapidly precipitated as ice near the poles. Such a redistribution of mass, Muller and Morris argue, would have changed the Earth's rotation rate rapidly enough to induce shear in Earth's liquid outer core and so disrupt the generation of the geomagnetic field. According to their theory, the geomagnetic field might have responded to such

Correspondence to: D.A. Schneider, Woods Hole Oceanographic Institution, Woods Hole, MA 02543, USA. impact events by collapsing entirely, later to be regenerated in the opposite polarity. This mechanism could explain the immediate cause of at least some of the many known geomagnetic polarity reversals of the past.

The apparent association of specific geomagnetic polarity reversals and impact events has long been considered [e.g. 3]; however, most recent evidence suggests that impacts do not show a general tendency to be immediately followed by polarity reversals. For example, of the four cases where impact ejecta and polarity reversal stratigraphies can be compared in the same sections, three have not indicated a reversal closely following the impact: microtektites of the Ivory Coast were deposited just after a geomagnetic reversal $[4,5]$; impact remnants found in mid-Pliocene age deep-sea sediments from the Southern Ocean [6] are well separated from any magnetic reversal boundaries [7], as is the case for tektite relics of 
the well-studied Cretaceous/Tertiary boundary [8] which occurs during the Chron C29R reversed polarity interval [9], about $200 \mathrm{kyr}$ before the next polarity reversal.

There does, however, remain one outstanding example supporting the notion that an impact might have triggered a geomagnetic polarity transition, even if this cannot be considered a general mechanism for causing other reversals. This is the Australasian impact, which has long been known to coincide closely in time with the BrunhesMatuyama polarity transition [3]. In this report we examine the detailed chronology of the Australasian impact event, the Brunhes-Matuyama geomagnetic polarity reversal, and global climate change to assess the possibility of a linkage by abrupt climate cooling and magnetic field disruption, as described by the Muller and Morris model.

Although no crater has yet been unambiguously identified, the Australasian impact event is well known from the study of distant ejecta, mostly in the form of tektites and microtektites, which were dispersed over Australia, southeast Asia, and much of the Indian and western Pacific Oceans. Indeed, the immense magnitude of the event is reflected in the size of the Australasian strewnfield which covers as much as one tenth of Earth's surface [10]. The age of the Australasian impact is known to be about 730,000 yr based on radiometric ages of these tektites and the stratigraphic position of microtektites found in deepsea sediments of the region $[3,10,11,12]$. The deep-sea record is of particular interest because, contrary to the case with most tektite finds on land, microtektites in deep-sea sediments remain embedded in their original stratigraphic position. Such sediments are known to retain a remanent magnetization which often preserves an excellent record of past behavior of the Earth's magnetic field [13] and can also provide a global paleoclimate record by means of oxygen isotope variations [14].

Recent studies of microtektite-bearing sediment cores from the Australasian strewnfield have confirmed the original association of the impact and reversal events and determined that this impact probably preceded the Brunhes-Matuyama polarity reversal by some $12-15 \mathrm{kyr}[12,15]$. Although such an age difference is usually consid- ered negligible from the perspective of geologic time scales, reversals of Earth's magnetic field are thought to occur even more rapidly than this, perháps within as little as 3-4 kyr [16]. Thus a 12-15 kyr interval between impact and reversal events is somewhat longer than would be expected if the impact had triggered this reversal. The uncertainty in the duration of the interval between the two events is, however, large $( \pm 5-6$ kyr) and so these prior results, while intriguing, are not entirely satisfactory for testing in detail the connection between the Australasian impact and the Brunhes-Matuyama polarity reversal.

\section{Examination of ODP Leg 124 Sites}

To examine better the possible connection between these two events, we have studied two deep-sea sediment cores recently obtained by the Ocean Drilling Program during Leg 124 from marginal basins of the Indonesian archipelago [17]. These sites were good candidates for detailed study because (1) the locations were well within the known limits of the Australasian strewnfield, (2) initial paleomagnetic measurements (from shipboard reports) indicated that these sediments retain a strong, generally stable record of Earth's magnetic field, and (3) the sedimentation rates (and hence temporal resolution expected) as estimated from the depths of well-dated biostratigraphic and magnetostratigraphic datums are nearly six times greater than in any core previously studied in this context.

We examined sediments from one site in the Sulu Sea (ODP Site 769) and one from about 500 $\mathrm{km}$ distant in the Celebes Sea (ODP Site 767) (Fig. 1). From ODP Site 769, we chose to analyze Core $769 \mathrm{~A}-7 \mathrm{H}$ on the basis of the shipboard pass-through magnetometer data which suggested that a relatively well-preserved paleomagnetic signal was recorded across the Brunhes-Matuyama boundary and that the interval below the reversal boundary would not be obscured by a core break (as is the case with the adjacent Hole 769B). From ODP Site 767 we studied Core 767B-6H, which spanned the appropriate interval, in an effort to duplicate the record from widely spaced sites in separate depositional basins. 
We analyzed the paleomagnetic signature of sediment samples using standard progressive alternating field demagnetization treatment and computed directions using principal component analysis [18]. Each of the samples was subsequently given an anhysteretic remanent magnetization (ARM) to use as a normalization factor for relative paleointensity estimates [19]. After paleomagnetic analyses were completed sediment samples were disaggregated and treated with $0.1 \mathrm{M}$ $\mathrm{HCl}$ (to remove the carbonate fraction), a $20 \%$ solution of $\mathrm{H}_{2} \mathrm{O}_{2}$ (to remove residual organics) and $5 \%$ sodium hexametaphosphate (to aid disaggregation). We then wet-sieved the samples and visually searched the $>125 \mu \mathrm{m}$ and 63-125 $\mu \mathrm{m}$ size fractions for microtektites using a binocular microscope. We counted objects $>125 \mu \mathrm{m}$ (Table 1) which could be unambiguously identified in a single pass as microtektites and obvious microtektite fragments identifiable by their characteristic shapes (Fig. 2) and glassy appearance in reflected light.

The paleomagnetic record from both continuous and discrete sample measurements of these Site 769 sediments clearly shows the location of the Brunhes-Matuyama boundary (Fig. 3), which is centered at $62.27 \mathrm{~m}$ below seafloor (mbsf). Although this core was not azimuthally oriented, the polarity boundary is apparent from the general decrease in intensity, the abrupt $180^{\circ}$ declination change and the shift of inclination from low negative to positive values, in agreement with our expectations for a reverse to normal polarity transition at this low-latitude site $\left(9^{\circ} \mathrm{N}\right)$. Below the reversal, a narrow zone of anomalous directions occurs at about $63.6 \mathrm{mbsf}$. The magnetiza-

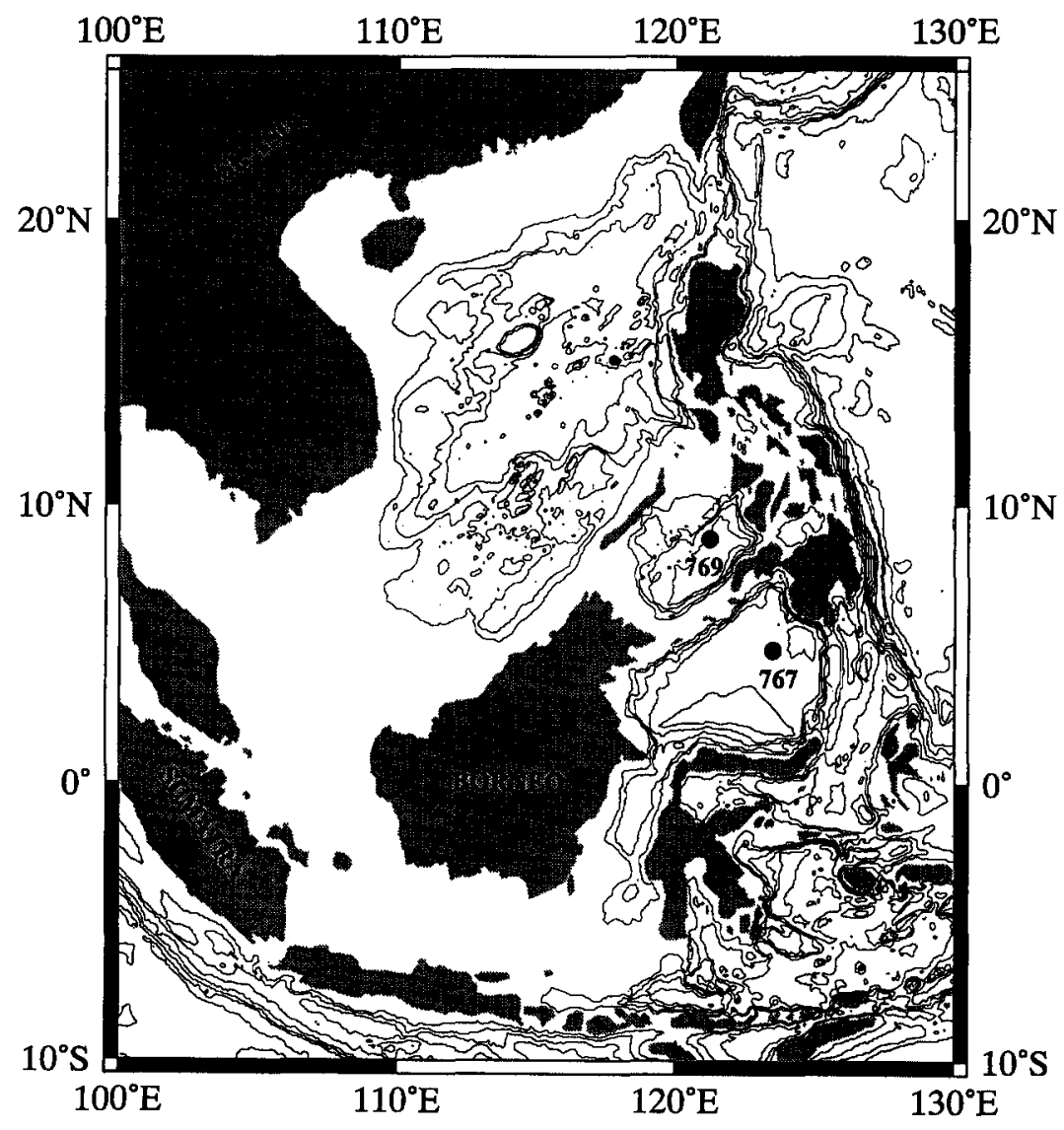

Fig. 1. Location of Leg 124 Ocean Drilling Program sites studied in the Sulu and Celebes basins. Reported results are from Cores 767B-6H and 769A-7H taken from Sites $767\left(4^{\circ} 47^{\prime} \mathrm{N}, 123^{\circ} 30^{\prime} \mathrm{E}\right.$; water depth $\left.4905 \mathrm{~m}\right)$ and $769\left(8^{\circ} 47^{\prime} \mathrm{N}, 121^{\circ} 18^{\prime} \mathrm{E}\right.$; water depth 3645 m). Contour interval of $1000 \mathrm{~m}$ is shown. 


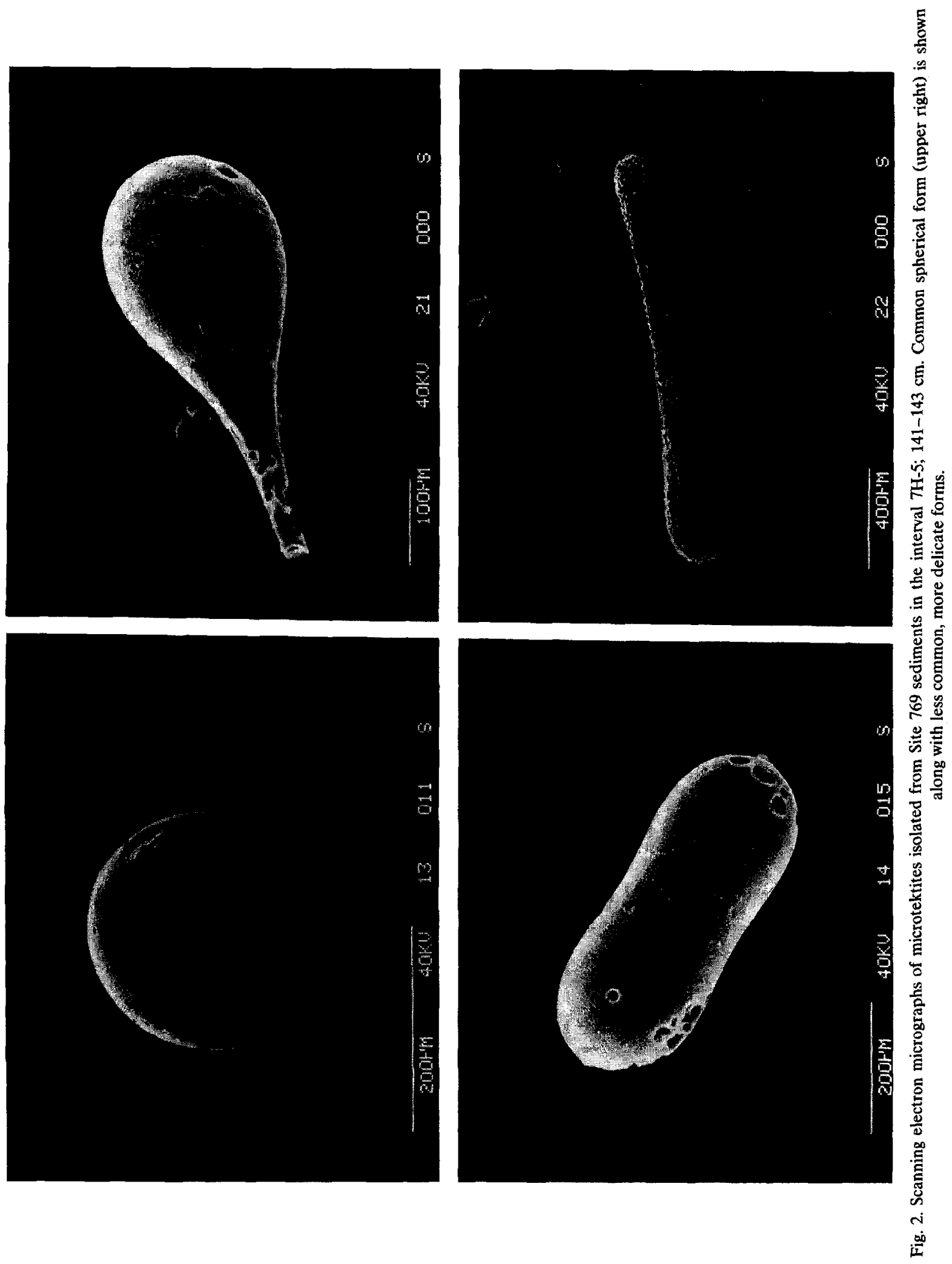




\section{ODP $769 A$}

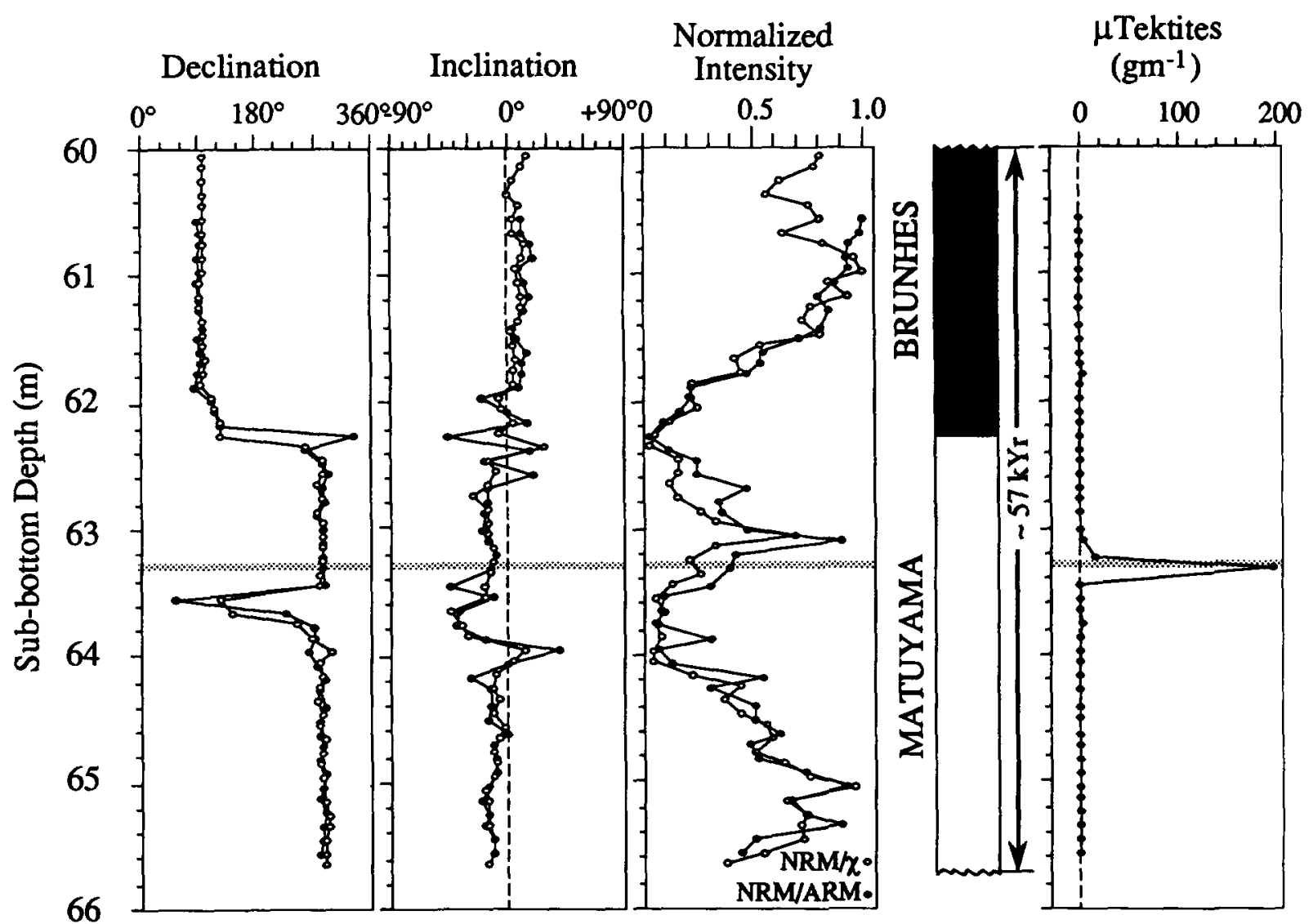

Fig. 3. Paleomagnetic and microtektite abundance stratigraphies from Site 769 sediments. Solid points indicate results from discrete sample paleomagnetic measurements; open points are from continuous (shipboard) pass-through magnetometer measurements. Directions of continuous measurements are after $10 \mathrm{mT}$ demagnetization. Discrete sample directions are determined by fitting progressive alternating field demagnetization trajectories. Declinations are given with respect to the double fiducial line on the work half sections. Intensity is normalized by ARM magnetization (for discrete measurements) and by low-field susceptibility (for continuous measurements). Microtektite abundance data reflect the number of microtektites (or obvious microtektite fragments) in the $>125 \mu \mathrm{m}$ size fraction picked. Abundances are given in number per gram of wet sediment.

tion of this zone is, however, quite low, and discrete sample results from this interval do not show well-defined demagnetization trajectories, suggesting that these scattered directions may reflect the inability of the sediments to record the true field direction over this low-intensity interval. We have estimated relative paleointensities from both discrete and continuous measurements using ARM intensity (for discrete sample measurements) and magnetic susceptibility (for continuous measurements) as normalizing factors. Both methods show the same pattern, with two distinct intervals of low field intensity within the core, one associated with the Brunhes-Matuyama directional reversal and one centered about $1.5 \mathrm{~m}$ below this boundary.

Our analysis of Site 769 sediments revealed that the peak in microtektite abundance occurs at $63.31 \mathrm{mbsf}$, about $1 \mathrm{~m}$ below the BrunhesMatuyama boundary (Fig. 3). The microtektite layer is particularly rich and well defined, with some $97 \%$ of the microtektites appearing within a $10 \mathrm{~cm}$ stratigraphic interval. At the peak sample level, we readily counted 1107 microtektites in one $5.6 \mathrm{~g}$ sample. The simple shape of the microtektite abundance curve, with an abrupt lower 


\section{ODP $767 B$}

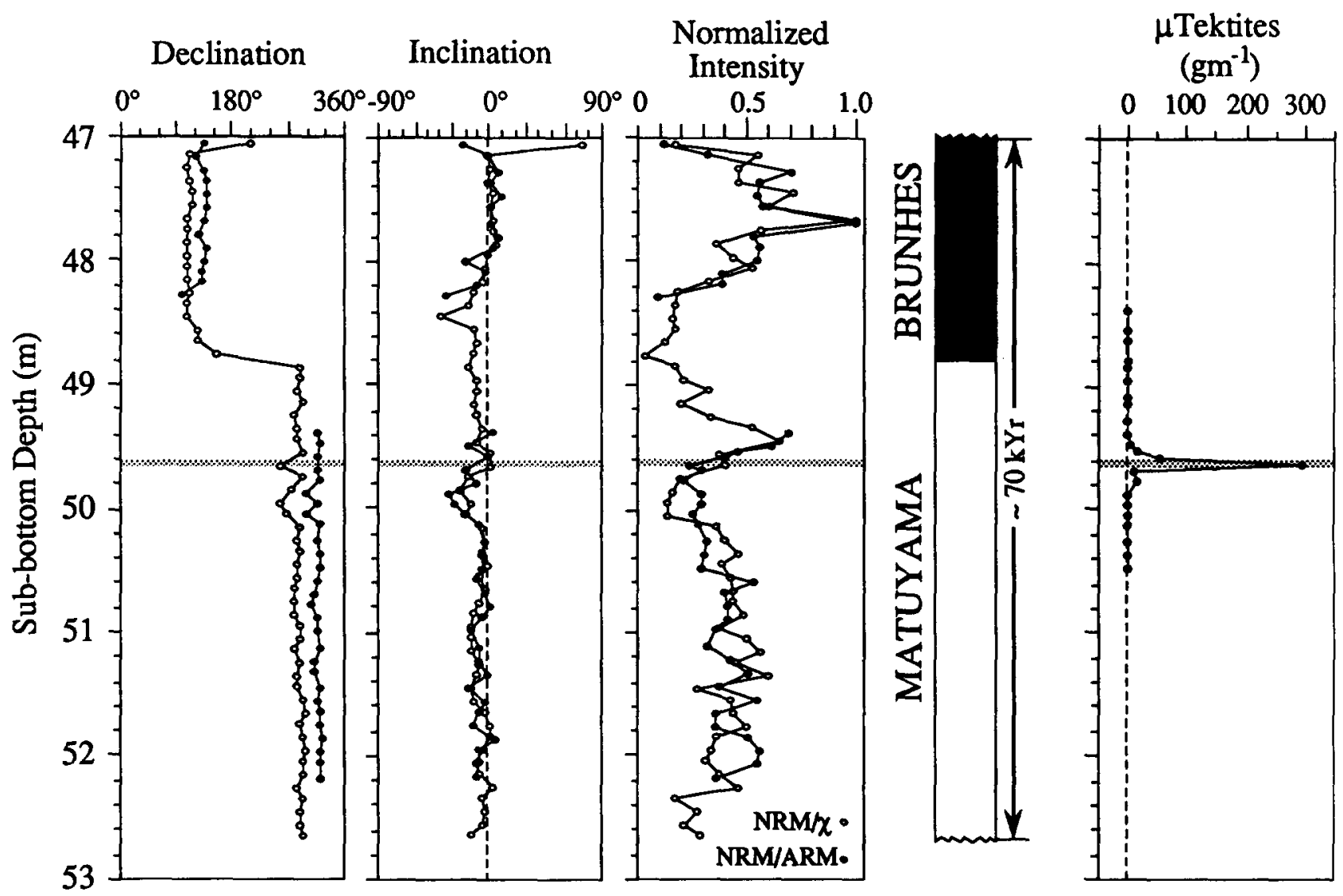

Fig. 4. Paleomagnetic and microtektite abundance stratigraphies from Site 767 sediments. Plotting conventions are the same as those in Fig. 3, except that the microtektite abundance in the interval from 48.3 to 49.3 mbsf is calculated by dividing the absolute number of microtektites found in the dry residues by the presumed weight of the original wet sediment samples ( $7.2 \mathrm{~g}$ ).

boundary and a rapidly tapering upper boundary, further suggests that only a very minor amount of reworking by bioturbation has occurred in the Site 769 record [22,23].

As was found for Site 769 , the continuous paleomagnetic stratigraphy of the Site 767 core shows a clear record of the Brunhes-Matuyama reversal, which is located at $48.8 \mathrm{mbsf}$ (discrete sampling of the boundary itself was not possible, this level having already been heavily sampled by other workers studying transitional field directions). The reversal is again displayed by a decrease in intensity, an abrupt $180^{\circ}$ declination shift and a change in inclination from low negative to positive values. As with Site 769 sediments, those from Site 767 show a zone of low magnetization intensity about $1 \mathrm{~m}$ below the Brunhes-Matuyama boundary in both the discrete and continuous measurements. With these sediments, however, the demagnetization trajectories appear more stable and no anomalous directions are seen in this low-intensity zone.

Our analysis of the sediments from Site 767 revealed the microtektite abundance peak to be at 49.63 mbsf (Fig. 4). As with Site 769, the microtektite layer at Site 767 is quite distinct, with $86 \%$ of the microtektites found within a 10 $\mathrm{cm}$ interval. The peak number of microtektites counted (1066 microtektites counted in one $3.6 \mathrm{~g}$ sample) gives an even higher concentration at this site than at Site 769. Although our single-pass counting of obvious specimens probably repre- 
TABLE 1

Microtektites counted in the $>125 \mu \mathrm{m}$ size fraction

\begin{tabular}{lcc}
$\begin{array}{l}\text { Core-Section } \\
\text {-Interval }\end{array}$ & $\begin{array}{c}\text { MBSF } \\
(\mathrm{m})\end{array}$ & $\begin{array}{c}\text { Wet Weight } \\
(\mathrm{g})\end{array}$ \\
\hline
\end{tabular}

\section{$O D P 767 B$}

$\begin{array}{cccr}06 \mathrm{H}-2-014 & 48.64 & 7.20^{*} & 0 \\ 06 \mathrm{H}-2-029 & 48.79 & 7.20^{*} & 14 \\ 06 \mathrm{H}-2-034 & 48.84 & 7.20^{*} & 0 \\ 06 \mathrm{H}-2-045 & 48.95 & 7.20^{*} & 0 \\ 06 \mathrm{H}-2-060 & 49.10 & 7.20^{*} & 0 \\ 06 \mathrm{H}-2-065 & 49.15 & 7.20^{*} & 0 \\ 06 \mathrm{H}-2-077 & 49.27 & 7.20^{*} & 0 \\ 06 \mathrm{H}-2-088 & 49.38 & 4.01 & 0 \\ 06 \mathrm{H}-2-098 & 49.48 & 4.04 & 12 \\ 06 \mathrm{H}-2-103 & 49.53 & 4.32 & 79 \\ 06 \mathrm{H}-2-108 & 49.58 & 3.80 & 211 \\ 06 \mathrm{H}-2-113 & 49.63 & 3.60 & 1066 \\ 06 \mathrm{H}-2-118 & 49.68 & 3.56 & 32 \\ 06 \mathrm{H}-2-128 & 49.78 & 3.74 & 58 \\ 06 \mathrm{H}-2-138 & 49.88 & 3.45 & 0 \\ & \text { ODP } 769 A & & \end{array}$

$\begin{array}{lllr}07 H-4-055 & 60.95 & 3.93 & 0 \\ 07 H-4-065 & 61.05 & 3.65 & 1 \\ 07 \mathrm{H}-4-077 & 61.17 & 3.54 & 0 \\ 07 \mathrm{H}-4-087 & 61.27 & 3.33 & 0 \\ 07 \mathrm{H}-4-101 & 61.41 & 3.22 & 0 \\ 07 \mathrm{H}-4-110 & 61.50 & 3.87 & 0 \\ 07 \mathrm{H}-4-121 & 61.61 & 3.93 & 0 \\ 07 \mathrm{H}-4-129 & 61.69 & 3.31 & 1 \\ 07 \mathrm{H}-4-137 & 61.77 & 3.69 & 7 \\ 07 \mathrm{H}-4-147 & 61.87 & 3.22 & 0 \\ 07 \mathrm{H}-5-007 & 61.97 & 2.96 & 0 \\ 07 \mathrm{H}-5-017 & 62.07 & 2.53 & 0 \\ 07 \mathrm{H}-5-027 & 62.17 & 2.52 & 0 \\ 07 \mathrm{H}-5-037 & 62.27 & 4.50 & 0 \\ 07 \mathrm{H}-5-047 & 62.37 & 4.81 & 0 \\ 07 \mathrm{H}-5-057 & 62.47 & 4.87 & 1 \\ 07 \mathrm{H}-5-067 & 62.57 & 4.33 & 0 \\ 07 \mathrm{H}-5-078 & 62.68 & 5.30 & 0 \\ 07 \mathrm{H}-5-088 & 62.78 & 5.31 & 0 \\ 07 \mathrm{H}-5-098 & 62.88 & 4.73 & 0 \\ 07 \mathrm{H}-5-111 & 63.01 & 5.27 & 3 \\ 07 \mathrm{H}-5-120 & 63.10 & 4.71 & 6 \\ 07 \mathrm{H}-5-132 & 63.22 & 8.72 & 127 \\ 07 \mathrm{H}-5-141 & 63.31 & 5.60 & 1107 \\ 07 \mathrm{H}-6-005 & 63.45 & 6.15 & 2 \\ 07 \mathrm{H}-6-015 & 63.55 & 5.40 & 0 \\ 07 \mathrm{H}-6-025 & 63.65 & 7.28 & 0 \\ 07 \mathrm{H}-6-036 & 63.76 & 5.53 & 14 \\ 07 \mathrm{H}-6-046 & 63.86 & 7.72 & 1 \\ 07 \mathrm{H}-6-056 & 63.96 & 2.55 & 0 \\ 07 \mathrm{H}-6-066 & 64.06 & 7.79 & 0 \\ 07 \mathrm{H}-6-077 & 64.17 & 2.97 & 0 \\ 07 \mathrm{H}-6-087 & 64.27 & 7.47 & 1 \\ 07 \mathrm{H}-6-101 & 64.41 & 2.99 & 0\end{array}$

Note that examined levels above and below those included in the table all had zero counts. Weights with an asterisk are for desiccated $6 \mathrm{~cm}^{3}$ residue samples which are assumed to have this original wet weight based on the typical sediment density sents an undercount of the total number of contained microtektites, the microtektite counts in both these ODP cores nevertheless exceed prior reports from deep-sea cores of the Australasian strewnfield and suggest a considerably higher concentration of microtektite fallout in this area than at other sites, with the possible exception of ODP Site 758 [20] and piston core $\mathrm{RC} 14-46$ from $7^{\circ} \mathrm{S}, 100^{\circ} \mathrm{E}$ in the easternmost Indian Ocean [21].

\section{Chronology of events}

In order to establish a detailed chronology for reversal and impact events, we need to consider possible errors in the stratigraphic position of the microtektites, in the recording of the paleomagnetic signal, and also in the estimates of sedimentation rates. The microtektites have, as mentioned, probably been redistributed slightly by bioturbation. To correct for this, it is probably most appropriate to consider the weighted mean of the microtektite distribution as the original stratigraphic level of the event (following the procedure of [12]). This places the original microtektite layer at $63.29 \mathrm{mbsf}$ at Site 769 and at $49.61 \mathrm{mbsf}$ at Site 767 . The paleomagnetic record may also be affected by post-depositional processes acting to depress the paleomagnetic signal a small amount (the 'lock-in depth') below the sediment-water interface. The depth of this effect in deep-sea sediments deposited at these relatively rapid rates is most likely about $16 \mathrm{~cm}$ [15] (although the exact value of lock-in depth in deep-sea sediments is admittedly somewhat uncertain; e.g., it has also been estimated at $7 \mathrm{~cm}$ [4]). Using a $16 \mathrm{~cm}$ correction, the true stratigraphic distance between the microtektite layer and reversal of magnetic directions is $118 \mathrm{~cm}$ at Site 769 and about $97 \mathrm{~cm}$ at Site 767. Note that these corrections only slightly modify the stratigraphic separation between the directional reversal and peak tektite levels as directly measured in these two cores.

The average sedimentation rate for Site 769 in this interval can be estimated at $10 \mathrm{~cm} / \mathrm{kyr}$ below the Brunhes-Matuyama boundary (calculated from the depth of the the upper Jaramillo boundary) and $9 \mathrm{~cm} / \mathrm{kyr}$ above (calculated from the depth of the NN19/NN20 boundary); at Site 767 it can be similarly estimated at $6 \mathrm{~cm} / \mathrm{kyr}$ below the Brunhes-Matuyama boundary and $8 \mathrm{~cm} / \mathrm{kyr}$ 
above. These sedimentation rates are, however, calculated on the basis of depths measured by means of the drill string (so-called 'meters below sea floor'). Because the comparison of staggered, adjacent holes at various ODP Sites indicates that $12 \%$ of the section is usually missing [24], complete composite depth sections can be expected to be some $14 \%$ longer than drilled depth. We thus modify our estimates of sedimentation rate to $11 \pm 1 \mathrm{~cm} / \mathrm{kyr}$ for Core $769 \mathrm{~A}-7 \mathrm{H}$ and $8 \pm 1 \mathrm{~cm} / \mathrm{kyr}$ yr for Core $767 \mathrm{~B}-6 \mathrm{H}$, based on the difference between the two bracketing estimates (above and below the Brunhes-Matuyama boundary) after correction for a presumed $14 \%$ expansion of the composite section. This modification thus acts to reduce the estimated age difference between two events recorded within a single core.

Using these values for sedimentation rate, and assuming that a $16 \mathrm{~cm}$ magnetic lock-in depth is appropriate, these records indicate a substantial delay between the impact event and the intensity drop that led to the field reversal. In particular, the first intensity decrease after the impact (recorded at both sites by sediments at least $20 \mathrm{~cm}$ above the microtektite layer, suggesting $36 \mathrm{~cm}$ of true stratigraphic offset) appears to have occurred about 4 kyr years afterwards. Even in the unlikely case that the magnetization was instantly locked in, a delay of some $2 \mathrm{kyr}$ is indicated.

These records show that the geomagnetic field had entered into a period of low intensity about 6 kyr before the impact, had recovered in intensity at about the time of the impact and continued to increase in intensity for about $4 \mathrm{kyr}$ afterward, before again decreasing in intensity and ultimately reversing polarity. Although the tektitegenerating event may have approximately coincided with the beginning of the first recovery of field intensity (the degree of coincidence depends on exactly what depth is assumed for the lock-in of magnetization), we would have difficulty ascribing this intensity increase to the impact. Although comparatively little is known about the secular variation of field intensity, we would generally expect intensity to fluctuate about some mean value with a time constant of perhaps several thousand years [25]. In these records, the geomagnetic field appears to have entered a lowintensity state some $6 \mathrm{kyr}$ before the impact and its subsequent recovery in intensity appears consistent with our general notion of normal field behavior. Thus there seems no need to involve the impact event to explain this particular increase in the magnetic field strength. If, alternatively, the first intensity low is viewed as part of the transitional field behavior, the beginning of the transition clearly precedes the impact.

Although paleointensity estimation is not without complications, the overall pattern with two intensity lows appears well founded. Both normalization parameters (ARM and magnetic susceptibility) generate similar paleointensity records showing these two distinct low-intensity intervals. Furthermore, very similar paleointensity records are recorded at two distant sites, located in separate depositional basins. Thus it is unlikely that the overall paleointensity pattern is controlled by any local sedimentological effect. The large magnitude of this intensity variation (three-fold or more is indicated at both sites) suggests that these changes were likely to have been of global extent, reflecting a change in the dipole field strength.

Unfortunately, few paleomagnetic records of sufficient detail and duration are available to confirm this history of intensity variation with similar records from other parts of the globe. One possible comparison, however, is with Lake Tecopa sediments in California [26], which also show a low-intensity interval just prior to the Brunhes-Matuyama reversal. Using the average sedimentation rate (as was calculated from the location of Brunhes-Matuyama, Jaramillo and the Cobb Mountain reversals) suggests that the secondary low-intensity feature seen in the Lake Tecopa record occurred 20-30 kyr before the Brunhes-Matuyama mid-point. This does not match our estimates for the duration of this interval particularly well, but this is perhaps not entirely unexpected given the inherent uncertainties in assuming constant sedimentation in the Lake Tecopa depositional environment.

We note that the best estimate of the age difference between the microtektite fall and the mid-point of the reversal of magnetic field direction is $11 \mathrm{kyr}$ from the Site 769 record and $12 \mathrm{kyr}$ from the Site 767 record, in very good agreement mutually and with the previous estimates $[12,15]$. The high sedimentation rate records presented 
here well constrain the duration of this interval; but more importantly, they chronicle the delay between the impact and the first subsequent decrease in geomagnetic field intensity.

\section{Testing the climate link}

The triggering mechanism suggested by Muller and Morris to account for the near coincidence of impact events and magnetic reversals depends on

\section{ODP 769A}



a sudden climate cooling caused by the impact. They suggest that this global cooling leads do a drop in sea level and an increase of polar ice volume, lowering the Earth's moment of inertia and causing an increase in rotational velocity which induces shear in the outer core. According to their model, this glaciation-induced shear eventually builds to the point where it disrupts the generation of the magnetic field.

The results from the high sedimentation rate sections show that, in detail, the timing of the Australasian impact, geomagnetic field evolution and global climate change does not follow the predicted pattern. Indeed, the timing of the impact in relation to resolvable global climatic fluctuations appears to be in complete contradiction with the Muller and Morris hypothesis. Although it had been suggested on the basis of lower resolution records that the Australasian impact event was immediately followed by colder climate [27], comparison of the microtektite and the oxygen isotope records from Site 769 shows the opposite. ${ }^{18} \mathrm{O}$ measurements from planktonic foraminifera in ODP Hole 769A [28] show oscillations indicative of global ice volume changes and these allow the timing of the microtektite event to be tied to global climate conditions. As both microtektites and foraminifera tests are expected to be similarly affected by bioturbation, there are no significant post-depositional offsets to complicate the stratigraphic alignment of these records. Their

Fig. 5. Comparison of global ice volume record with paleomagnetic and microtektite stratigraphies. Note that in the original isotopic analysis [28] values derived from the alternative species ( $N$. dutertrei, $\square$ ) were adjusted to the primary species used $(G$. ruber, $O)$ based on paired measurements of the systematic offset. The relative age scale is derived assuming a constant sedimentation rate of $11 \mathrm{~cm} / \mathrm{kyr}$ over the interval. The relative sea level scale is constructed using a $0.11 \%$ shift in $\delta^{18} \mathrm{O}$ for each $10 \mathrm{~m}$ sea level change [28]. Microtektite abundance data $(\bullet)$ are shown as number per gram of wet sediment. Normalized paleointensity $(\boldsymbol{a})$ is from ARM normalization of discrete sample data, scaled to a range of 0-250 (to match the microtektite abundance scale). To facilitate comparison of these records, the Brunhes-Matuyama (B-M) boundary (the level of the abrupt reversal of paleomagnetic directions) and the ARM-normalized paleointensity results have been shifted upward by $16 \mathrm{~cm}$ to compensate for the depression of the magnetic lock-in zone, as described in the text. 
direct comparison (Fig. 5) indicates that the Australasian impact occurred toward the end of a glacial interval (presumably Oxygen Isotope Stage 20 [15]) and that the next significant climate shift was the warming transition to the subsequent interglacial (Stage 19). At least within the limits of resolution of this record (about $1000 \mathrm{yrs}$ ), there is no evidence for climate cooling after the impact. It thus remains difficult to support the hypothesis of glaciation-induced shear being been built up in the outer core during the critical interval after the impact: a deglaciation was, in fact, occurring. Indeed, if any case is to be made for an important climatic effect following the impact, it might be for this subsequent climate warming. This warming is, however, well explained by Milankovitch orbital forcing [14] and so no extraordinary mechanism is required to account for it. Furthermore, the oxygen isotope record supports our estimate of an 11-12 kyr age difference between the impact and directional reversal of the magnetic field, in that these events appear to be separated by at least half of a precessional cycle (i.e., about $10 \mathrm{kyr}$ ).

The Australasian event has lent critical support to the perception that large impacts might trigger other geophysical changes such as magnetic field reversals or sudden climatic shifts. The detailed chronology from these high sedimentation rate sections clearly indicates that, other than its proximity in time, the Australasian impact event shows no obvious relation with evolution of the magnetic field, nor with any discernible ice volume increase prior to the Brunhes-Matuyama polarity transition. Thus, the sudden but short-lived effects of the Australasian impact appear to be inconsequential in comparison with the even more powerful, ongoing forces that drive geomagnetic and climatic changes.

\section{Acknowledgements}

We would like to thank the curatorial staff of the Ocean Drilling Program for facilitating our sampling and study of the cores. We would also like to express our appreciation and acknowledge the efforts of the Leg 124 shipboard paleomagnetists for generating valuable pass-through magnetometer data from these cores. We appreciate also the helpfulness and generosity of many mem- bers of the Lamont New Core Laboratory for lending us equipment and facilities for the wet sediment work. We especially appreciate Richard Muller's thoughtful and gracious review of the manuscript, particularly as he disagrees with our conclusions and thinks these new results do not contradict the Muller and Morris theory [Muller, pers. commun.]. This work was supported at Lamont by a statistical bootstrap method, using residual funds from a gift from ARCO and under a variety of grants from the National Science Foundation, with EAR88-17773 to DVK the closest program antecedent. Additional fellowship support for DAS was provided from the Education Office of Woods Hole Oceanographic Institution. This is Lamont-Doherty Geological Observatory contribution number 4937 and Woods Hole Oceanographic Institution contribution number 8043.

\section{References}

1 R.A. Muller and D.E. Morris, Geomagnetic reversals from impacts on the Earth, Geophys. Res. Lett. 13, 1177-1180, 1986.

2 R.A. Muller and D.E. Morris, Geomagnetic reversals driven by sudden climate changes, Eos Trans. AGU 70, 276, 1989.

3 B.P. Glass and B.C. Heezen, Tektites and geomagnetic reversals, Sci. Am. 217, 32-38, 1967.

4 B.P. Glass, D.V. Kent, D.A. Schneider and L. Tauxe, Ivory Coast microtektite strewn field: description and relation to the Jaramillo geomagnetic event, Earth Planet. Sci. Lett. 107, 182-196, 1991.

5 D.A. Schneider and D.V. Kent, Ivory Coast microtektites and geomagnetic reversals, Geophys. Res. Lett. 17, 163166, 1990.

6 S.V. Margolis, P. Claeys and F.T. Kyte, Microtektites, microkyrstites and spinels from a Late Pliocene asteroid impact in the Southern Ocean, Science 251, 1594-1597, 1991.

7 J.D. Hays and N.D. Opdyke, Antarctic radiolaria, magnetic reversals and climatic change, Science 158, 1967.

8 H. Sigurdsson, S. D'Hondt, M.A. Arthur, T.J. Bralower, J.C. Zachos, M. Van Fossen and J.E.T. Channell, Glass from the Cretaceous/Tertiary boundary in Haiti, Nature 349, 482-487, 1991.

9 A. Preisinger, E. Zobetz, A.J. Gratz, R. Lahodynsky, M. Becke, H.J. Mauritsch, G. Eder, F. Grass, F. Rogl, H. Strandner and R. Surenian, The Cretaceous/Tertiary boundary at the Gasau Basin, Austria, Nature 322, 794799, 1986.

10 B.P. Glass, M.B. Swincki and P.A. Zwart, Australasian, Ivory Coast and North American tektite strewn fields: size, mass and correlation with geomagnetic reversals and other 
earth events, Proc. Lunar Planet. Sci. Conf. 10, 2535-2545, 1979.

11 W. Gentner, B. Kleinmann and G.A. Wagner, New K-Ar and fission track ages of impact glasses and tektites, Earth Planet. Sci. Lett. 2, 83-86, 1967.

12 C.A. Burns, Timing between a large impact and a geomagnetic reversal and the depth of NRM acquisition in deepsea sediments, in: Geomagnetism and Paleomagnetism, F.J. Lowes et al. eds., pp. 253-261, Kluwer, 1989.

13 N.O. Opdyke, Paleomagnetism of deep-sea cores, Rev. Geophys. Space Phys. 10, 213-249, 1972.

14 J.D. Hays, J. Imbrie and N.J. Shackleton, Variations in the Earth's orbit: pacemaker of the Ice Ages, Science 194, 1121-1132, 1976.

15 P.B. deMenocal, W.F. Ruddiman and D.V. Kent, Depth of post-depositional remanence acquisition in deep-sea sediments: a case study of the Brunhes-Matuyama reversal and oxygen isotopic Stage 19.1, Earth Planet. Sci. Lett. 99, 1-13, 1990.

16 B.M. Clement and D.V. Kent, Latitudinal dependency of geomagnetic polarity transition durations, Nature 310 , 488-491, 1984.

17 C. Rangin, E.A. Silver et al., Proc. ODP, Init. Rep. 124, 1990.

18 J.L. Kirschvink, The least-squares line and plane and the analysis of paleomagnetic data, Geophys. J.R. Astron. Soc. 62, 699-718, 1980.

19 J.W. King, S.K. Banerjee and J. Marvin, A new rock magnetic approach to selecting sediments for geomagnetic intensity studies: application to paleointensity for the last 4000 years, J. Geophys. Res. 88, 5911-5921, 1983.

20 J. Smit, A.J.M. van Eijden and S.R. Troelstra, Analysis of the Australasian microtektite event, the Toba Lake event and the Cretaceous/Paleogene boundary, eastern Indian Ocean, Proc. ODP, Sci. Results 121, 297-355, 1991.

21 C.A. Burns, The Australasian microtektite layer: implications concerning their source area and their relationship to the Brunhes/Matuyama geomagnetic reversal, Ph.D. Thesis, Univ. Delaware, 1990.

22 B.P. Glass, Reworking of deep-sea sediments as indicated by the vertical dispersion of the Australasian and Ivory Coast microtektite horizons, Earth Planet. Sci. Lett. 6, 409-415, 1969.

23 W.F. Ruddiman and L.K. Glover, Vertical mixing of icerafted volcanic ash in North Atlantic sediments, Geol. Soc. Am. Bull. 83, 2817-2836, 1972.

24 J.W. Farrell and T.R. Janecek, Late Neogene paleoceanography and paleoclimatology of the northeast Indian Ocean (Site 758), Proc. ODP, Sci. Results 121, 297-355, 1991.

25 M.W. McElhinny and W.E. Senanayake, Variations in the geomagnetic dipole 1: the past 50,000 years, J. Geomagn. Geoelectr. 34, 39-51, 1982.

26 J.-P. Valet, L. Tauxe and D.R. Clark, The MatuyamaBrunhes transition recorded from Lake Tecopa sediments (California), Earth Planet. Sci. Lett. 87, 463-472, 1988.

27 B.P. Glass, Possible correlations between tektite events and climatic changes?, Geol. Soc. Am. Spec. Pap. 190, 251-256, 1982.

28 B.K. Linsley and M.T. von Breymann, Stable isotopic and geochemical record in the Sulu Sea during the last 750,000 years: assessment of surface water variability and paleoproductivity changes, Proc. ODP, Sci. Results 124, 379 396, 1991. 